Article

\title{
Synthesis and Performance of Iron Oxide-Coated Ceramsite in a Biotrickling Filter for Nitric Oxide Removal under Thermophilic Conditions
}

\author{
Han $\mathrm{Li}^{1,2}$, Ze Guo ${ }^{3}$, Dafu Wu ${ }^{1, *}$, Jing Fan ${ }^{2}$, Shaobin Huang ${ }^{4}$ and Shaofeng Zhou ${ }^{4}$ \\ 1 Postdoctoral Research Base, Henan Institute of Science and Technology, Xinxiang 453003, China; \\ lihanenjoy@hist.edu.cn \\ 2 School of Environment, Henan Normal University, Xinxiang 453007, China; fanjing@henannu.edu.cn \\ 3 Department of Human Resources, Henan Institute of Technology, Xinxiang 453003, China; h34@scut.edu.cn \\ 4 School of Environment and Energy, South China University of Technology, Guangzhou 510006, China; \\ chshuang@scut.edu.cn (S.H.); wangfei@hist.edu.cn (S.Z.) \\ * Correspondence: uau@hist.edu.cn; Tel.: +86-373-3040147
}

Received: 25 January 2018; Accepted: 26 February 2018; Published: 28 February 2018

\begin{abstract}
A novel medium consisting of iron oxide-coated porous ceramsite (modified ceramsite) was investigated for $\mathrm{NO}$ removal under thermophilic conditions in this study. We used a surface coating method with $\mathrm{FeCl}_{3} \cdot 6 \mathrm{H}_{2} \mathrm{O}$ as the modifier. When ceramsite was calcined for $4 \mathrm{~h}$ at $500{ }^{\circ} \mathrm{C}$, the surface $\mathrm{pH}$ value decreased to 3.46 , which is much lower than the isoelectric point of ceramsite, ensuring its surface was electropositive. The surface of modified ceramsite changed from twoto three-dimensional and exhibited excellent adsorption behavior to assist microbial growth; the maximum dry weight of the biofilm was $1.28 \mathrm{mg} / \mathrm{g}$. It only took 8 days for the biofilter constructed from the modified ceramsite to start up, whereas that packed with commercial ceramsite took 22 days. The NO removal efficiency of the biofilter did not decrease apparently at high NO inlet concentration of above $1600 \mathrm{mg} / \mathrm{m}^{3}$ and maintained an average value of above $90 \%$ during the whole operation period. Additionally, the morphological observation showed that the loss of the surface coating was not obvious, and the coating properties remained stable during long-term operation. The maximum $\mathrm{NO}$ inlet loading of the biotrickling filter was $80 \mathrm{~g} /\left(\mathrm{m}^{3} \cdot \mathrm{h}\right)$ with an average removal efficiency of 91.1\% along with a quick start-up when using the modified ceramsite filler. Thus, modified ceramsite can be considered a very effective medium in biotrickling filters for NO removal.
\end{abstract}

Keywords: iron oxide-coated porous ceramsite; biofilter; microbial growth; NO removal

\section{Introduction}

With the rapid industrial development achieved in recent years, the emission of flue gas has increased, which is strongly linked to air pollution levels. Flue gas from a powerplant consists of $\mathrm{CO}_{2}$, $\mathrm{SO}_{\mathrm{x}}, \mathrm{NO}_{\mathrm{x}}$ and $\mathrm{O}_{2}$, and the primary pollutants are $\mathrm{SO}_{\mathrm{x}}$ and $\mathrm{NO}_{\mathrm{x}}$. $\mathrm{NO}$ is the primary composition of $\mathrm{NO}_{x}$, particularly to flue gas, and accounts for about $90 \%$ [1]. Nitrogen oxides $\left(\mathrm{NO}_{\mathrm{x}}\right)$ from flue gas can cause acid rain and are the main substance during the formation process of photochemical smog. Besides, $\mathrm{NO}_{\mathrm{x}}$ can destroy the ozone, which brings a threat to human health and the environment [2]. For a long period of time, chemical and physical methods are the basis for the purification treatment of $\mathrm{NO}_{x}$ [3]. The typic techniques of simultaneous desulfurization and denitrification are widely used in atmospheric control [4], while being prohibitively expensive when dealing with large volumes of flue gas [5]. Furthermore, secondary pollutants can be produced and often need further treatment [6]. There have been emerging various new technologies to reduce $\mathrm{NO}_{\mathrm{x}}$ from flue gas [7-11]. Advances in microbiology, especially associated with the isolation of aerobic denitrifying bacteria, have revealed that 
microbial purification of volatile pollutants is a promising technique [12,13]. Microbial denitrification has rapidly become a new research focus. Bioprocesses using biotrickling filters and biofilters are emerging post-combustion control technologies that are potential alternatives for purification of gases containing small amounts of $\mathrm{NO}_{x}[14,15]$.

The packing material is the carrier of microorganisms in biofilters, and is the main location of immobilization and pollutant treatment [16]. Therefore, it is of great significance to choose suitable packing materials for effective operation of biofilters. To select a good packing material should consider the following factors: (a) packing material type, (b) packing porosity, (c) packing moisture capacity, (d) packing nutrient content, and (e) sorption characteristics of the packing surfaces. In addition, besides, it is essential to study the adsorption characteristics of the target chemical by the packing material to determine a suitable packing material.

A modified packing material is a microbe carrier surface coated with a modifier by physical and chemical reactions, thereby changing the primary physical and chemical properties of the packing material particle surface. Such modification can enhance the immobilization ability of the material and its adsorption capacity for certain specific substances. These favorable changes mean that packing material modification is widely used in wastewater treatment processes. Research has shown that $\mathrm{Fe}_{2} \mathrm{O}_{3}$ is more sensitive to bacteria than other packing material [17], which is probably because of its relatively higher point of zero charge (PZC) [18]. When an electrolyte oxide or amphoteric species is placed in water, the zwitterionic electric charge could change because of the different $\mathrm{pH}$ value of the solution. In addition, an electric double layer can form on the surface and generate electrophoresis when a voltage is applied. Adding some electrolyte to the water will compress the counter ion layer of the electric double layer. Conversely, adding a certain number of ions will result in minimum compression of the counter ion layer, a surface potential of zero, and no electrophoresis; this status is referred to as PZC. At this time, the solution $\mathrm{pH}$ is the $\mathrm{pH}$ of the isoelectric point of the oxide, which is indicated as PI. When the solution $\mathrm{pH}$ is higher than the PI ( $\mathrm{pH}>\mathrm{PI}$ ), amphoteric ions release protons and are negatively charged. When the $\mathrm{pH}$ of the solution is lower than the PI $(\mathrm{pH}<\mathrm{PI})$, zwitterions are protonated and thus positively charged. It was found that cell-induced and supernatant-induced reductions were combined to achieve favorable results in a biofilter modified with $\mathrm{Fe}_{2} \mathrm{O}_{3}$ [17]. Therefore, the use of $\mathrm{Fe}_{2} \mathrm{O}_{3}$ as a modifier to improve the surface properties of biofilters is attracting increasing attention [19]. In addition, Chen [20] assessed the effectiveness of sand covered with aluminum hydroxide by in situ precipitation over four months, and during this period, the sand was exposed to wastewater. Biogrowth in one set of columns was prevented by receiving chloride wastewater, while a parallel column was used to treat dechlorination wastewater. The results showed that the aluminum content of coated sand decreased by about $25 \%$ in the first two weeks, and remained relatively stable, much higher than that of uncoated sand. Similarly, the zeta potential of the coated sand decreased from above $+20 \mathrm{mV}$ to below $-70 \mathrm{mV}$ in the first two weeks, which was still much more electropositive than that of uncoated sand. In the absence of biogrowth, the zeta potential of coated sand subsequently remained approximately unchanged, and most importantly, it exhibited excellent performance for bacteria removal. This study assesses the technological potential and economic implications of metallic hydroxide coating of filter media.

The natural inert packing material typically used in biotrickling filters include rock wool-compost [21], zeolite [22], and the compound packing material lightweight ceramsite [23]; most of these are silicate minerals or organic polymer and are negatively charged. Generally, it is believed that the adsorption capacity of such packing material for negatively charged bacteria is weak; after modification, their adsorption capacity can be greatly increased. Modification technology has gradually been developed for nearly a decade. The basic theory of such modification is to change the physical and chemical properties of the original packing material or its surface by physical and chemical methods [24,25]. Guzek [26] analyzed modified packing material and noted that the physical and chemical properties of the surface coating affected filler adsorption capacity. Because the coating had a large surface area, numerous surface adsorption sites, and high surface roughness and porosity, the modified packing material 
exhibited great advantages over their unmodified equivalents in biofiltration. Modified fillers can be divided into two categories: one is the addition of components during the manufacturing process, such as nano-modified ceramics and modified polypropylene biological packing material. The other involves changing the surface properties of the filler matrix. For example, activation of modified zeolite membranes at $500{ }^{\circ} \mathrm{C}$ was found to effectively promote catalytic cracking deposition of silane in the zeolitic pores, which resulted in considerable improvement of adsorptive performance [27]. There have been multiple investigations of modified packing material used for wastewater treatment; however, their application in gas pollutant treatment has seldom been reported [28-30].

Packing material modification is beneficial to improve packing physical parameters, enhance the biofilm capacity in a reactor, and effectively increase the reaction area of pollutants and biological membranes. Thus, packing material modification affects biological filter processing capacity, buffering capacity, and the volume load of the whole biofilter system, ultimately improving the removal ability of $\mathrm{NO}_{\mathrm{x}}$ by a biological trickling filter. In this study, we selected a commonly used commercial ceramic as the matrix for modification, as it has a regular shape and stable property, most of all, it could be easily achieved with low lost. We investigate the surface modification method to improve the surface properties of the packing material to provide a more favorable growth environment for microorganisms, and then use the modified material in a thermophilic biofilter reactor, as shown in Figure 1. This novel biofilter is used to treat NO from simulated flue gas under thermophilic conditions. The performance of the biofilter, including the start-up rate and NO removal efficiency, is investigated. The coating properties after a long period of operation are examined. The results of this study provide theoretical guidance for the practical application of iron oxide-based ceramsite in biotrickling filters for NO removal.

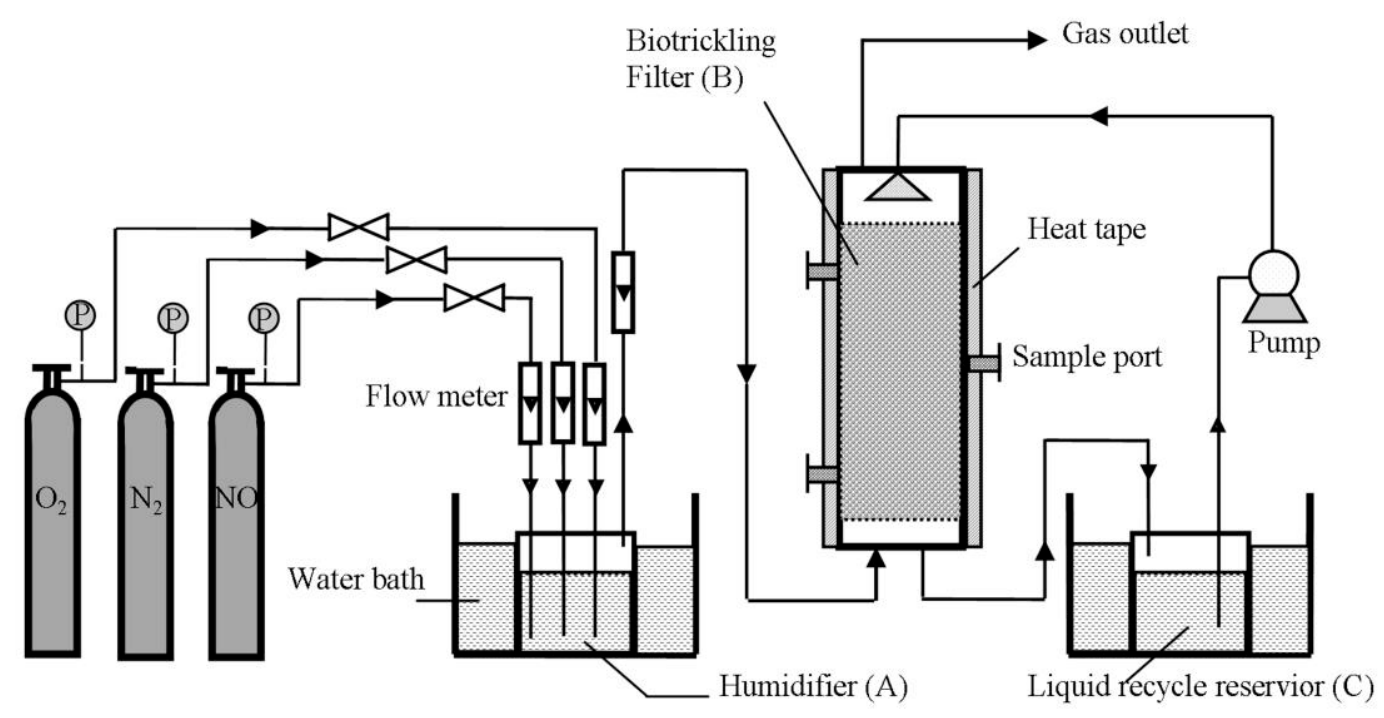

Figure 1. Experimental setup of a biotrickling filter system.

\section{Materials and Methods}

\subsection{Microbes}

The strain Chelatococcus daeguensis TAD1 was isolated by our group from the biofilm of an on-site biotrickling filter at a coal-fired power plant (Guangzhou, China). The 16S rRNA sequences (1385 bp) of $C$. daeguensis were searched for similarities in blastn (NCBI, Bethesda, MD, USA). The sequence data for the strain has been submitted to the DDBJ/EMBL/Gen-Bank databases under accession No. HM000004 [31]. 


\subsection{Growth Medium}

The trickling nutrient liquid included the following components (in $\mathrm{g} / \mathrm{L}$ ): $\mathrm{KNO}_{3}, 1.0$ (in the start-up stage); $\mathrm{NaCl}, 4.7$; disodium succinate, 5.0; $\mathrm{Na}_{2} \mathrm{HPO}_{4}, 7.9 ; \mathrm{KH}_{2} \mathrm{PO}_{4}, 1.5 ; \mathrm{MgSO}_{4} \cdot 7 \mathrm{H}_{2} \mathrm{O}$, $0.1 ; 1 \mathrm{~mL}$ of trace element solution. The trace element solution consisted of (in $\mathrm{g} / \mathrm{L}$ ): EDTA, 50.0; $\mathrm{CaCl}_{2}, 5.5 ; \mathrm{MnCl}_{2} \cdot 4 \mathrm{H}_{2} \mathrm{O}, 5.06 ; \mathrm{FeSO}_{4} \cdot 7 \mathrm{H}_{2} \mathrm{O}, 5.0 ; \mathrm{ZnSO}_{4}, 2.2 ; \mathrm{CoCl}_{2} \cdot 6 \mathrm{H}_{2} \mathrm{O}, 1.61 ; \mathrm{CuSO}_{4} \cdot 5 \mathrm{H}_{2} \mathrm{O}, 1.57$; $\left(\mathrm{NH}_{4}\right)_{6} \mathrm{Mo}_{7} \mathrm{O}_{2} \cdot 4 \mathrm{H}_{2} \mathrm{O}, 1.1$. All chemicals were analytical-grade reagents, commercially available, and used without further purification. NO (99.9\%) was obtained from Foshu Kede Gas Co., Guangzhou, China. $\mathrm{N}_{2}(99.99 \%)$ and $\mathrm{O}_{2}(99.99 \%)$ were obtained from Guangzhou Gas Co., Guangzhou, China.

\subsection{Biotrickling Filter Setup and Operation}

The bench-scale biofilter reactor shown in Figure 1 was used in this study. The reactor was constructed of cylindrical plexiglass. The height and diameter of the reactor were 80 and $10 \mathrm{~cm}$, respectively. Iron oxide-coated ceramsite (or commercial ceramsite as a reference) was used as the packing material. The packing space was in the height of $20 \mathrm{~cm}$. The reactor was wrapped with heating tape, and then covered with a layer of fiberglass as insulator. The heating tape was controlled by a digital temperature controller, which maintained the reactor temperature at $50 \pm 1{ }^{\circ} \mathrm{C}$.

Inlet gas was obtained by mixing pure $\mathrm{NO}, \mathrm{N}_{2}$, and $\mathrm{O}_{2}$, while the three gases were mixed in a humidifier before entering the reactor. The simulated inlet gas was preheated by passing through the humidifier, which was set in a thermostatic water bath $\left(50 \pm 1^{\circ} \mathrm{C}\right)$. The inlet NO concentration was controlled by adjusting the flow rate of each gas through the flow meter before entering the humidifier. The constant-volume (3 L) liquid reservoir for nutrient recycling was also controlled at $50 \pm 1^{\circ} \mathrm{C}$ by a thermostatic water bath. The recycling liquid was pumped to the upper surface of the packing materials by a peristaltic pump which was set at a flow rate of $250 \mathrm{~mL} / \mathrm{min}$ to maintain sufficient moisture. A 500-mL aliquot of the liquid medium was drawn off and renewed with fresh nutrient solution containing 1\% C. daeguensis TAD1 daily to confirm that the denitrifying strain C. daeguensis TAD1 was the dominant type of bacteria in the microbial community and provide necessary nutrients for microbial growth. The NO concentration in the influent gas was varied by regulating the mass flow meters. The main conditions for biotrickling filter setup and operation are listed in the Table 1.

Table 1. The operating conditions for each packing material.

\begin{tabular}{lccccccc}
\hline $\begin{array}{l}\text { Packing } \\
\text { Material }\end{array}$ & $\begin{array}{c}\text { Start } \mathrm{Up} \\
(\mathbf{d})\end{array}$ & $\begin{array}{c}\mathrm{NO}_{3}{ }^{-}-\mathbf{N} \\
\text { Concentration }(\mathbf{m g} / \mathrm{L})\end{array}$ & $\mathbf{p H}$ & $\begin{array}{c}\text { Operation } \\
(\mathbf{d})\end{array}$ & $\begin{array}{c}\text { NO Inlet } \\
\left(\mathbf{g} / \mathbf{m}^{3}\right)\end{array}$ & EBRT (s) & $\mathrm{T}\left({ }^{\circ} \mathrm{C}\right)$ \\
\hline $\begin{array}{l}\text { Ceramsite } \\
\text { Modified }\end{array}$ & 22 & $136-145$ & $7-7.5$ & 35 & $0.2-2$ & 88 & $50 \pm 1$ \\
ceramsite & 8 & $136-145$ & $7-7.5$ & 35 & $0.2-2$ & 88 & $50 \pm 1$ \\
\hline
\end{tabular}

\subsection{Analytical Methods}

Nitrate was analyzed by ion chromatography (DX-500; Dionex Corporation, Sunnyvale, UK). The column used was Dionex ionpac AS14. To measure the thermophilic removal of NO in a continuous gas stream, the $\mathrm{NO}, \mathrm{N}_{2}$ and $\mathrm{O}_{2}$ fluxes were controlled by a mass flow controller (FM310-MT, Opine, Tianjin, China). The NO concentration at both the inlet and outlet was analyzed by a flue gas analyzer (350Pro, Testo, Baden-wurttemberg, Germany) at 10-h intervals. The NO concentrations at the inlet and outlet of the biofilter were also measured. The performance of the biofilter was quantified by its NO removal efficiency (RE) and Inlet loading, which were calculated as follows:

$$
\mathrm{RE}=\frac{\mathrm{C}_{\mathrm{in}}-\mathrm{C}_{\text {out }}}{\mathrm{C}_{\text {in }}} \times 100 \%
$$

Inlet loading $\left(\mathrm{L}, \mathrm{g} /\left(\mathrm{m}^{3} \cdot \mathrm{h}\right)\right)$ :

$$
\mathrm{L}=\frac{\mathrm{Q} \cdot \mathrm{C}_{\mathrm{in}}}{\mathrm{V}}
$$


where $\mathrm{V}$ is the packing volume of the filler in the biofilter reactor $(\mathrm{L}) ; \mathrm{Q}$ is the gas flow rate $(\mathrm{L} / \mathrm{h})$, it was set at $60 \mathrm{~L} / \mathrm{h}$ in this study; and $\mathrm{C}_{\text {in }}$ and $\mathrm{C}_{\text {out }}$ are the inlet and outlet NO concentrations $\left(\mathrm{g} / \mathrm{m}^{3}\right)$, respectively.

The biomass concentration attached to the packing materials was measured by the oven-drying method as follows [32]. Several ceramsites were removed from the biofilter to place in an oven at $105^{\circ} \mathrm{C}$, and then dried to a constant weight. W1 represented the dry weight, including the biofilm and carriers. The dry carriers were soaked in hydrochloride acid $(1 \mathrm{~mol} / \mathrm{L})$ solution for $2 \mathrm{~h}$ at $80{ }^{\circ} \mathrm{C}$, carried out ultrasonic cleaning for $1 \mathrm{~h}$, and then rinsed with water until all the biofilm was cleaned away. Finally, drying treatment to the clean carriers until a constant-weight carrier was formed. The dry weight of the clean carriers was marked as W2. Thus, the biomass weight was obtained by subtracting W2 from W1. The biomass concentration attached to the packing materials was calculated as the ratio of the biomass weight to that of the dry carriers.

\subsection{Modified Ceramic}

\subsubsection{Ceramic Modification}

The purpose of this experiment is to make the surface of ceramic with positive charge group composition. Therefore, the modified agent containing metal cations can be used. $\mathrm{FeCl}_{3} \cdot 6 \mathrm{H}_{2} \mathrm{O}$ is cost low, and with low microbial toxicity, so we chose it as modifier. Ceramic modification involved three steps: surface pretreatment, soaking, and high-temperature calcination [28]. In the first step, the material was soaked in $\mathrm{H}_{2} \mathrm{SO}_{4}$ with a 1:500 volume ratio for $24 \mathrm{~h}$, washed with water to a $\mathrm{pH}$ near neutral, and placed in a tray for drying at $105^{\circ} \mathrm{C}$. In the soaking step, the material was soaked with modifier of $\mathrm{FeCl}_{3} \cdot 6 \mathrm{H}_{2} \mathrm{O}(1 \mathrm{~mol} / \mathrm{L})$ and then dried at a comparatively low temperature (usually $105^{\circ} \mathrm{C}$ ). The main purpose of this step is to induce the modifier to fully attach to the surface of the carrier. The material was stirred every $30 \mathrm{~min}$ to ensure full contact between the modifier and material. The surface preparation of selected carriers was conducted to restore the surface activity to achieve the strongest adhesion of the modifier. High-temperature calcination was performed to make the $\mathrm{FeCl}_{3}$ coating evaporate from the solution and then metal oxide was deposited on the filler surface. The calcination temperature and time directly affected the performance of the modified material.

\subsubsection{Evaluation Parameters of the Modified Ceramic}

The preparation and use of modified ceramic require some of the physical and chemical parameters to be evaluated. Physicochemical parameters of fillers include porosity, density, surface $\mathrm{pH}$, surface composition, isoelectric point (PI), and the amount of coating.

Surface $\mathrm{pH}$

To measure the surface $\mathrm{pH}$ of the ceramic, $10 \mathrm{~g}$ of the selected ceramic was weighed accurately and placed in a beaker. Distilled water $(90 \mathrm{~mL})$ was added and then the suspension was stirred for $10 \mathrm{~min}$. The $\mathrm{pH}$ of the solution was then measured, which was defined as the surface $\mathrm{pH}$.

Porosity

Ceramic porosity was determined as the ratio between the pore volume and total volume of the ceramic. The filter layer gap ratio and filter particle shape, uniformity, and degree of compaction affect ceramic porosity. The measurement method is as follows:

First, measure the density of the ceramic: $100 \mathrm{~mL}$ (V1) water was added to the $200 \mathrm{~mL}$-pycnometer, then put into $100 \mathrm{~g}$ dried ceramic slowly, tilt and shake the bottle to get rid of gas, read the bottle surface V2 after standing $24 \mathrm{~h}$, which can have the formula of packing density $\rho$

$$
\rho\left(\mathrm{g} / \mathrm{cm}^{3}\right)=\mathrm{G} /(\mathrm{V} 2-\mathrm{V} 1)
$$


where $\mathrm{G}$ is mass of dried ceramic $(\mathrm{g}), \mathrm{V} 1$ is the volume of added water $\left(\mathrm{cm}^{3}\right), \mathrm{V} 2$ is the volume after $24 \mathrm{~h}\left(\mathrm{~cm}^{3}\right)$.

Once you have measured the density of the ceramic, put the ceramic after drying in the cartridge and the filler is filtered with water for some time, then measure the filter layer volume $\mathrm{V}$. The porosity $\left(\mathrm{m}_{0}\right)$ is calculated as follows

$$
\mathrm{m}_{0}(\%)=100 \times(1-\mathrm{G} / \rho \mathrm{V})
$$

where $\rho$ is packing density of dried ceramic $\left(\mathrm{g} / \mathrm{cm}^{3}\right), \mathrm{V}$ is the volume of filter layer volume $\left(\mathrm{cm}^{3}\right)$.

Isoelectric Point

PI values were obtained by the analysis of empirical constants and potentiometric titration depending on the nature of the oxide.

\section{Coating Content}

Coating content $(\mathrm{M})$ was determined per unit mass in units of $\mathrm{mg} / \mathrm{g}$. Coating amount directly affects the surface properties of the modified ceramic. To measure M, $50 \mathrm{~g}$ of ceramic was weighed accurately with an analytical balance, which is referred to as M1. M was calculated by the following equation,

$$
\mathrm{M}(\mathrm{mg} / \mathrm{g})=1000(\mathrm{M} 2-\mathrm{M} 1) / \mathrm{M} 1,
$$

where M1 is the ceramic mass before modification $(\mathrm{g})$ and $\mathrm{M} 2$ is the ceramic mass after modification $(\mathrm{g})$.

\section{Results and Discussion}

Usually, modification effect is evaluated according to the biomass amount when biofilm formation is completed. Besides, the experimental parameters for modified material before and after use including physical and chemical indicator nature, film forming properties, and pollutant removal can be compared.

\subsection{Modification Conditions}

The biotrickle reactor used for evaluating modification conditions is a smaller one with an operation period of 20 days. The height and diameter of the reactor were 50 and $8 \mathrm{~cm}$, respectively. The packing space was in the height of $10 \mathrm{~cm}$ and the operation steps are just the same as the start-up period described in Section 2.3.

\subsubsection{Calcination Temperature}

In the calcination process, the ceramsite was modified with the modifier $\mathrm{FeCl}_{3} \cdot 6 \mathrm{H}_{2} \mathrm{O}$ concentration of $1 \mathrm{~mol} / \mathrm{L}$ by calcination for $3 \mathrm{~h}$ at a temperature of 300,400,500, or $600{ }^{\circ} \mathrm{C}$. The prepared modified ceramsite samples were used in a small biological trickling filter tower for microbial biofilm experiments. The dry weight of each biofilm was measured when the biofilm of biotrickling filter was stable.

As shown in Figure 2, the dry weight of the biofilm was $1.01 \mathrm{mg} / \mathrm{g}$ for the ceramsite modified at a calcination temperature of $300{ }^{\circ} \mathrm{C}$ and it increased by about $20 \%$ to reach $1.21 \mathrm{mg} / \mathrm{g}$ when the calcination temperature was $400{ }^{\circ} \mathrm{C}$. The mass increased a bit more when the calcination temperature was raised up to $500{ }^{\circ} \mathrm{C}$ and then the mass remained constant when the calcination temperature was $600{ }^{\circ} \mathrm{C}$. Based on these results, we selected $500{ }^{\circ} \mathrm{C}$ as the calcination temperature for ceramsite modification. 


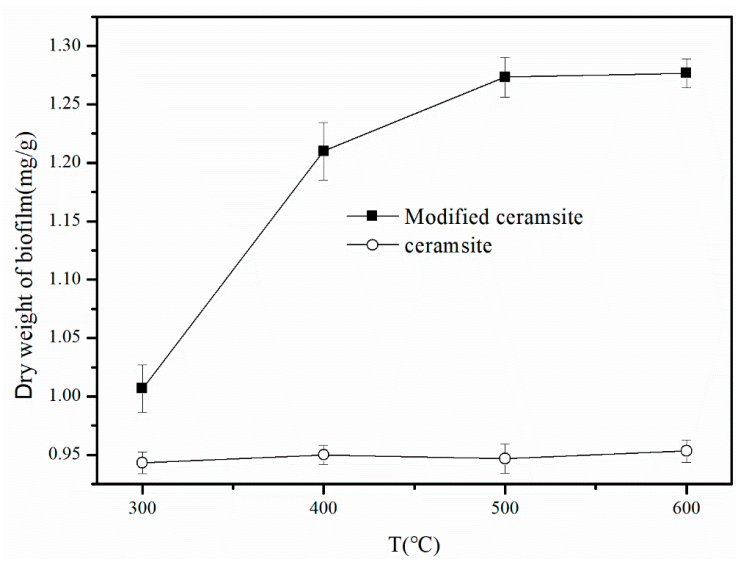

Figure 2. Dry weight of biofilm under different calcination temperature $\left(300,400,500\right.$ and $\left.600{ }^{\circ} \mathrm{C}\right)$ of the modified ceramsite.

\subsubsection{Calcination Time}

To determine the effect of calcination time on ceramsite modification, experiments were performed with a modifier concentration of $1 \mathrm{~mol} / \mathrm{L}$, calcination temperature of $500{ }^{\circ} \mathrm{C}$, and calcination times of $1,2,3,4,5$, and $6 \mathrm{~h}$. The prepared modified ceramsite samples were then used in small biological trickling filter towers for microbial biofilm experiments. The dry weight of each biofilm was measured when the biofilm of each biotrickling filter was stable.

Figure 3 reveals that there was no obvious modification effect when the calcination time was $1 \mathrm{~h}$, because the dry weight of biofilm was only $1.01 \mathrm{mg} / \mathrm{g}$, which was only a slight increase over that of the case for unmodified ceramsite. The same phenomenon occurred when the calcination time was $2 \mathrm{~h}$. The dry weight of the biofilm increased sharply, reaching $1.2 \mathrm{mg} / \mathrm{g}$ (an increase of nearly 20\%) when the calcination time was extended to $3 \mathrm{~h}$. When the calcination time was $4 \mathrm{~h}$, the maximum dry weight of the biofilm of $1.28 \mathrm{mg} / \mathrm{g}$ was obtained and then stayed quite stable with the further lengthening of calcination time. According to the change of the dry weight of the biofilm, the crystal state of the surface was stable after calcination for $4 \mathrm{~h}$, and the number of microbes adsorbed on the surface did not change when the calcination time was prolonged further. Therefore, we determined that the optimal calcination time was $4 \mathrm{~h}$ at $500^{\circ} \mathrm{C}$.

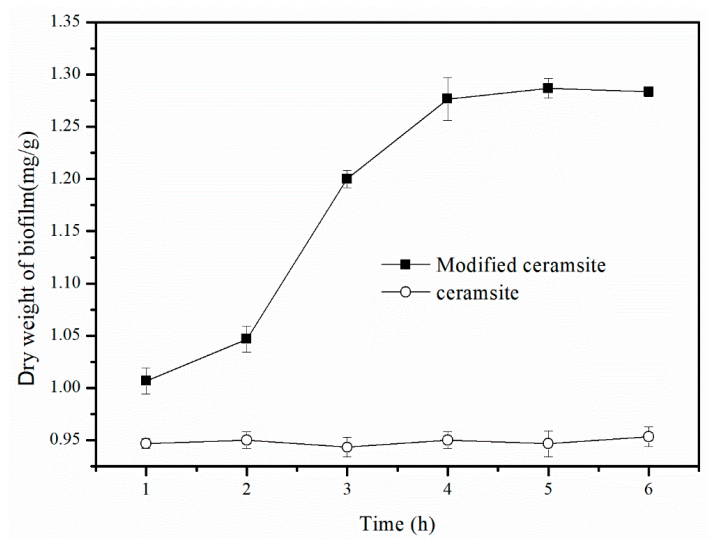

Figure 3. Dry weight of biofilm under different calcination time $(1,2,3,4,5$ and $6 \mathrm{~h})$ of the modified ceramsite.

\subsection{Properties of Modified Ceramics}

The purpose of modification is to change the surface properties of the ceramic which is reflected by the physical and chemical parameters, purification efficiency, and stability of the modified ceramic. 
The modification conditions were determined experimentally. The surface physical and chemical properties of the modified ceramsite were suitable to realize strong adsorption and immobilization of nitrogen removal bacteria. The physical and chemical properties of the ceramsite surface were changed by modification. Characteristic parameters of the unmodified and modified ceramsite samples are listed in Table 2. SEM images of the unmodified and modified ceramics are presented in Figures 4 and 5 , respectively.

Table 2. Characteristic parameters of ceramsite and modified ceramsite.

\begin{tabular}{lcccccccc}
\hline Shape & $\begin{array}{c}\text { Diameter } \\
(\mathbf{m m})\end{array}$ & $\begin{array}{c}\text { Coating Contents } \\
(\mathbf{m} \mathbf{g} / \mathbf{g})\end{array}$ & $\begin{array}{c}\text { Density } \\
\left(\mathbf{g} / \mathbf{m}^{3}\right)\end{array}$ & $\begin{array}{c}\text { Surface Area } \\
\left(\mathbf{m}^{\mathbf{2}} / \mathbf{m}^{\mathbf{3}}\right)\end{array}$ & $\begin{array}{c}\text { Porosity } \\
(\mathbf{\%})\end{array}$ & PI & Surface $\mathbf{~} \mathbf{H}$ \\
\hline Before & sphere & $3-5$ & 0 & 1.98 & 398 & 48 & $0.7-3$ & 6.95 \\
After & sphere & $3-5$ & 42.1 & 2.36 & 398 & 55 & 8.5 & 3.46 \\
\hline
\end{tabular}

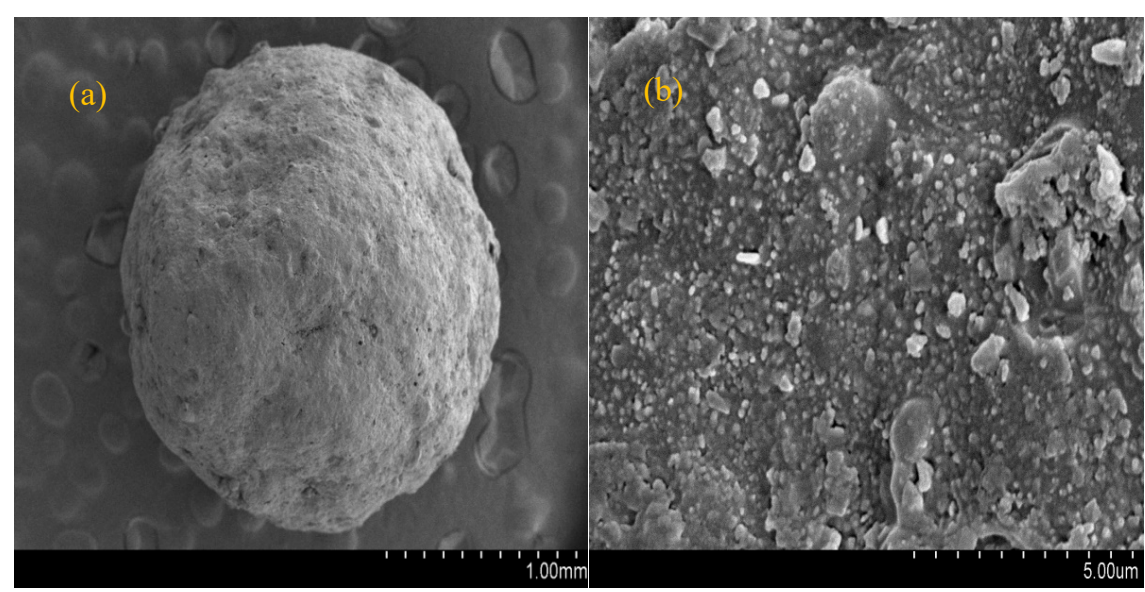

Figure 4. Scanning electron micrograph of commercial ceramsite: (a) $1 \mathrm{~mm}$; (b) $5 \mu \mathrm{m}$.

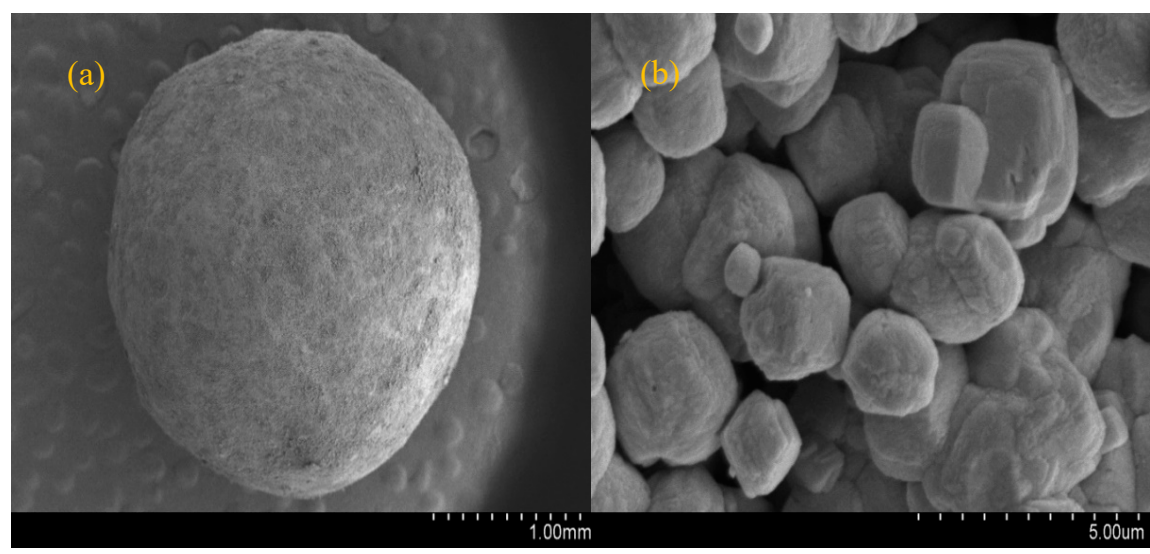

Figure 5. Scanning electron micrograph of modified ceramsite: (a) $1 \mathrm{~mm}$; (b) $5 \mu \mathrm{m}$.

Table 1 indicates that the shape and particle size of ceramsite did not change after modification, but its density increased by $17 \%$ and porosity increased by about $15 \%$. In addition, modification increased the PI of ceramsite by more than four times and lowered the surface $\mathrm{pH}$ to 3.46. The surface $\mathrm{pH}$ is much lower than PI, which confirms that the surface is electropositive.

Figures 4 and 5 illustrate that the modified ceramsite has a rougher surface compared with that of ceramsite; modification changed its two-dimensional rough surface into a three-dimensional surface. The modified ceramsite surface was thickly covered with crystals. The crystal morphology was trigonal and consistent with hematite, confirming the existence of a stable form of iron oxide on the modified 
ceramic surface. That is, the surface coating process successfully coated iron oxide on the ceramic surface. There are studies showing that crystal structure affects adsorption performance. For example, Bruno et al. [33] studied the sorption of phosphorus from aqueous solutions by crystalline and amorphous blast furnace slags. They found that the two slags had quite different sorption properties for phosphorus even though they had nearly the same compositions, which was attributed to their dissimilar morphological structures resulting in different surface areas. The surface area of crystalline slag was $0.65 \mathrm{~m}^{2} / \mathrm{g}$, whereas that of amorphous slag was only $0.5 \mathrm{~m}^{2} / \mathrm{g}$.

\subsection{Start-up Performance of the Biotrickling Filter}

A previous study revealed that NO injection is not required until the denitrifying ratio reaches $80 \%$ and a macroscopic yellow biofilm appears [34]. Therefore, we replaced $\mathrm{NO}$ with $\mathrm{KNO}_{3}$ during the start-up period of the biotrickling filter. During the start-up period, the trickling rate was controlled at $250 \mathrm{~mL} / \mathrm{min}$ and $50 \%$ of the trickling liquid was replaced every other day. To maximize cell adhesion to the packing medium, the reactor was operated in closed-loop mode. The $\mathrm{NO}_{3}{ }^{-}$removal efficiency was considered the indicating factor in the start-up period. To obtain a reliable variation of the $\mathrm{NO}_{3}{ }^{-}-\mathrm{N}^{-}$ removal efficiency, a stable initial $\mathrm{NO}_{3}{ }^{-}-\mathrm{N}$ concentration for each day of the start-up period should be maintained, hence, the external nitrogen $\left(\mathrm{KNO}_{3}\right)$ concentration of the newly added trickling liquid was variable due to the residual $\mathrm{NO}_{3}{ }^{-}-\mathrm{N}$ concentration and the initial $\mathrm{NO}_{3}{ }^{-}-\mathrm{N}$ concentration was ranged from 136 to $145 \mathrm{mg} / \mathrm{L}$ for each day during the whole startup phase. The results are presented in Figure 6. Generally, the formation of a biofilm in biological trickling filters is more difficult and requires a longer time compared with that in common biological filters [35]. This is mainly because the moving liquid has a shearing action on the packing; therefore, the adherent microbes must overcome this scouring force to grow. In addition, because microbial cells are covered in negative charges under natural conditions and commonly used packing material surfaces are also usually negatively charged, charge repulsion might hinder microbe adsorption on the filler. Thus, the start-up period of biotrickling filters is usually long (more than 20 days) with various type packing materials [36,37]. Some researchers [38] reported an enhanced system which featured a shorter start-up period with the inoculation of the enriched denitrifying bacteria significantly reducing its acclimation time to 17 days. As shown in Figure 6, when commercial ceramsite was used as a filler, the biofilm took about 22 days to fully mature. Conversely, it only took 8 days for the biotrickling filter to start up when the modified ceramsite was used as the packing material. That is, ceramsite modification greatly shortened the start-up period. These results indicated that the biofilter packed with the modified filler could be quickly started up by inoculation with $C$. daeguensis TAD1.

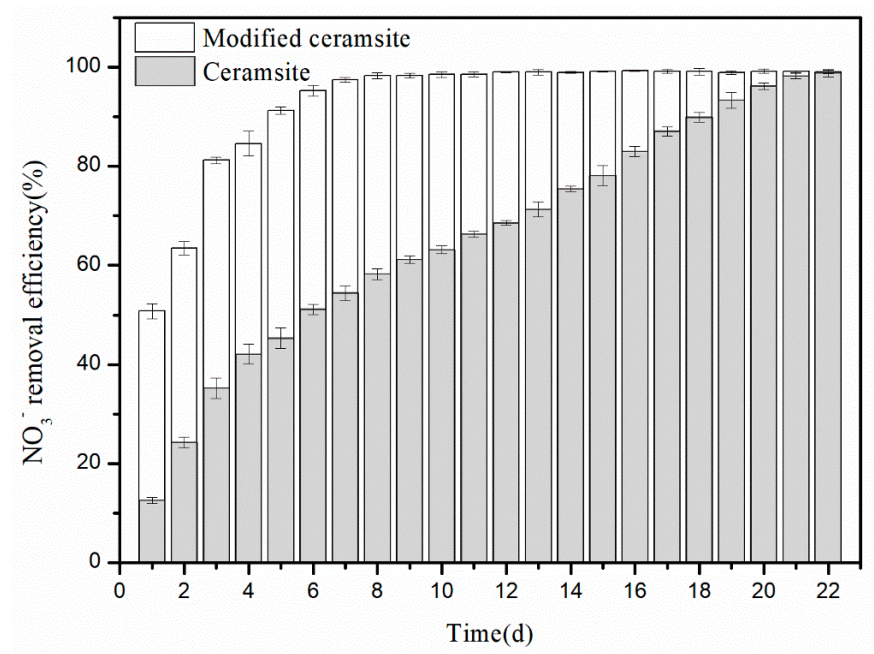

Figure 6. $\mathrm{NO}_{3}{ }^{-}$removal efficiencies for modified ceramsite and commercial ceramsite as fillers in the biotrickling filter during the start-up period. 


\subsection{Performance of the Biotrickling Filter}

We used the modified ceramsite and commercial ceramsite as packing material in different biofilters and then tested the biofilter performance for $\mathrm{NO}$ removal under thermophilic conditions for 35 days after start-up. The bench-scale biofilter reactors (see Figure 1) were operated at high temperature $\left(\sim 50^{\circ} \mathrm{C}\right)$. The circulating fluid $(\mathrm{pH}=7)$ was sprayed at a rate of $250 \mathrm{~mL} / \mathrm{min}$, and the empty bed residence time (EBRT) was $88 \mathrm{~s}$. The inlet NO concentration was increased from 200 to $2000 \mathrm{mg} / \mathrm{m}^{3}$. The results are shown in Figure 7. For the biofilter with modified ceramsite, the removal efficiency was less than $80 \%$ during the first three days, which was because NO suddenly became the only nitrogen source when it replaced $\mathrm{KNO}_{3}$. However, the removal efficiency increased appreciably after 3 days. When the inlet NO concentration was increased from 200 to $2000 \mathrm{mg} / \mathrm{m}^{3}$ and EBRT was $88 \mathrm{~s}$, the removal efficiency of NO did not apparently decrease and maintained an average value of above $90 \%$ during the remaining 32 days of treatment. The biofilter containing commercial ceramsite displayed lower removal efficiency compared with that of the biofilter with the modified ceramsite; in particular, at a high NO inlet concentration of above $1600 \mathrm{mg} / \mathrm{m}^{3}$, the removal efficiency was less than $80 \%$. The biofilter with the modified filler exhibited stable and efficient NO removal performance compared with that of the unmodified case, and this effect was more prominent at high NO inlet concentration. The iron oxide-modified ceramsite improved the performance of the biofilter for NO removal.

The maximum inlet loading of the modified ceramsite biofilter was $80 \mathrm{~g} /\left(\mathrm{m}^{3} \cdot \mathrm{h}\right)$ with an average removal efficiency of $91.1 \%$, which revealed that the maximum elimination capacity was much higher than that of some typical biofilters as shown in Table 3. In general, the capability of the modified ceramsite biofilter for NO removal was excellent and presented a promising practical application for NO removal with strong adaptability under various conditions especially for the high inlet loading.

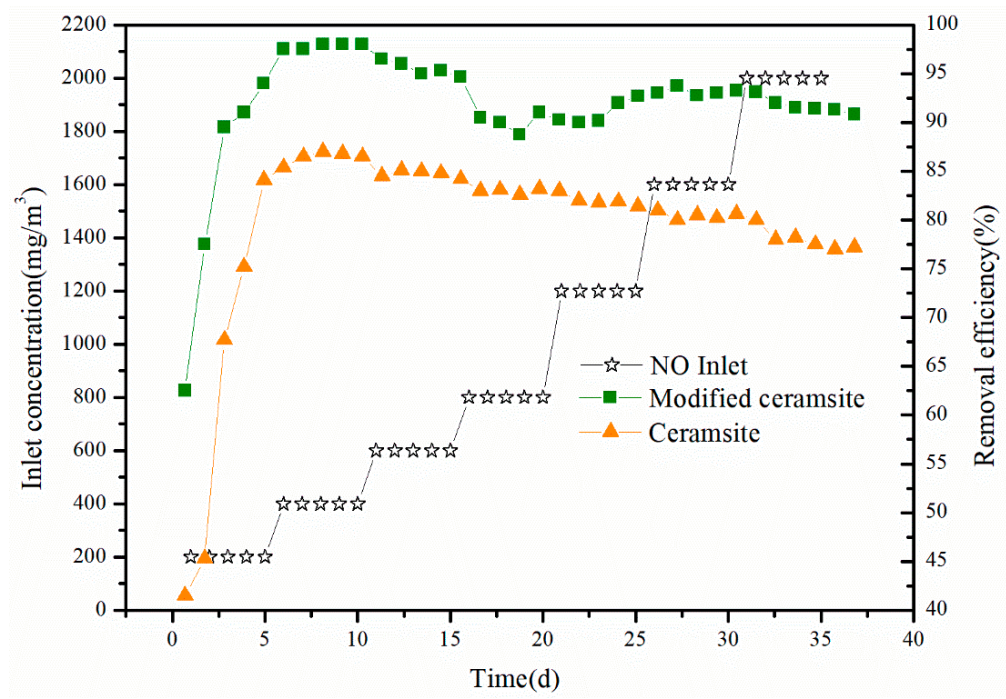

Figure 7. NO concentrations and removal efficiencies for modified ceramsite and natural ceramsite as fillers in the biotrickling filter during the operation period.

Table 3. Performance of some typical bioreactors for NO removal.

\begin{tabular}{|c|c|c|c|c|c|c|c|}
\hline Filler & $\begin{array}{c}\text { Temperature } \\
\left({ }^{\circ} \mathrm{C}\right)\end{array}$ & $\mathrm{O}_{2}(\%)$ & $\begin{array}{l}\text { NO Inlet } \\
\left(\mathrm{mg} / \mathrm{m}^{3}\right)\end{array}$ & $\begin{array}{l}\text { EBRT } \\
\text { (min) }\end{array}$ & $\begin{array}{l}\text { Inlet Loading } \\
\left(\mathrm{g} /\left(\mathrm{m}^{3} \cdot \mathrm{h}\right)\right)\end{array}$ & RE (\%) & Reference \\
\hline modified PVC & $50 \pm 0.5$ & $1-3$ & 315 & 1 & 18.75 & 75 & [39] \\
\hline soil & 20-37 & - & 335 & - & - & 60 & [40] \\
\hline ceramics & $50 \pm 0.5$ & $2-20$ & 800 & 1.8 & 26.67 & $80-92$ & [41] \\
\hline ceramics & $30 \pm 0.5$ & $2-20$ & 800 & 1 & 48 & 63 & [42] \\
\hline woven fiber & $50 \pm 1$ & 8 & 2000 & 0.7 & 163.6 & 89.8 & [34] \\
\hline modified ceramsite & $50 \pm 1$ & 8 & 2000 & 1.5 & 80 & 91.1 & This study \\
\hline
\end{tabular}




\subsection{Analysis of Surface Stability}

The performance of ceramsite as a filler was greatly improved following modification with an iron oxide-based coating on its surface. To investigate the stability of the ceramic surface coating, the modified ceramsite was packed in a biotrickling filter before start-up and operation over a continuous period of 90 days, and then removed for morphological observation (Figure 8). Compared with that of the unused modified filler surface (Figure 5), the crystal structure became clearer. This was attributed to the gradual loss of the amorphous component during operation, whereas the stable crystal structure was not removed so easily; therefore, the surface of the iron oxide-coated ceramsite remained intact. The loss of the surface coating was not obvious under the investigated experimental conditions, indicating that the coating is relatively stable when used in a biological filter system during long-term operation.

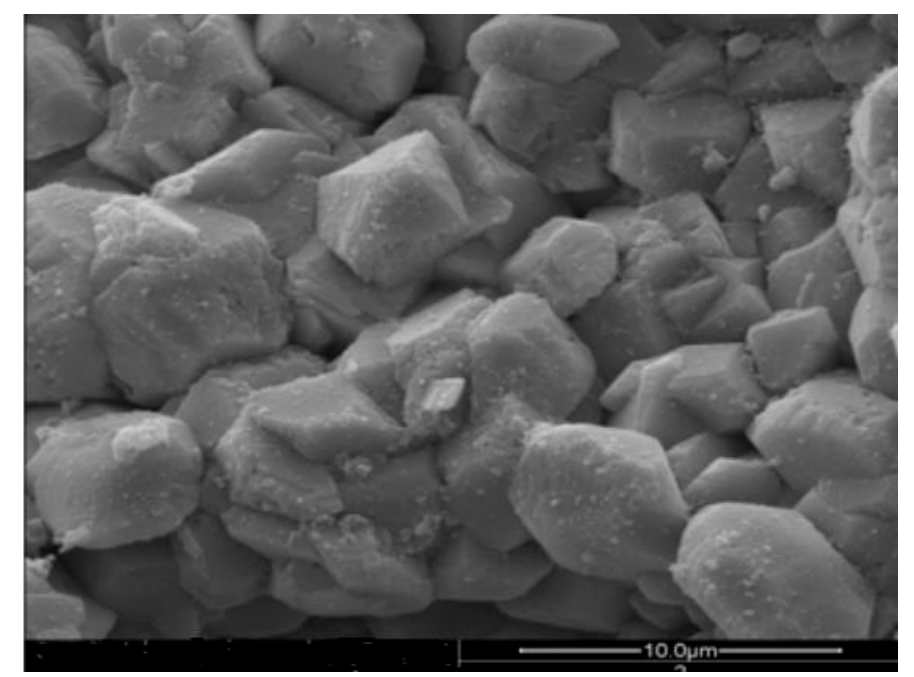

Figure 8. Scanning electron micrograph of modified ceramic after 2160-h use.

\section{Conclusions}

The performance of iron oxide-modified ceramsite as a filter medium in a biotrickling process was investigated. SEM results suggested that the modified ceramsite possessed a uniform interconnected crystal structure, which was more suited to microbial growth than the compact and closed pore structure of commercial ceramsite. It only took 8 days for the biotrickling filter with the modified ceramsite to start up, which was much shorter than the start-up period of the filter with commercial ceramsite. The filter packed with the modified filler displayed stable NO removal performance that was more efficient than that of the biofilter with the unmodified ceramsite; this effect was more prominent at high NO inlet concentration. The iron oxide-coated porous ceramsite thus improved the NO removal performance of the biofilter. The loss of the surface coating was not obvious under the experimental conditions and the coating remained relatively stable during operation for a long period. These observations reveal the promise of iron oxide-coated ceramsite as packing material in biotrickling filters for NO removal under thermophilic conditions.

Acknowledgments: This research was financially supported by the National Natural Science Foundation of China (grant nos. 51708184, and U1701243) and the Natural Science Foundation of Guangdong Province, China (2015A030313232).

Author Contributions: Professor Dafu Wu and Shaobin Huang conceived the experiments; Han Li designed and performed the experiments; Ze Guoand Jing Fan analyzed the data; Shaofeng Zhou contributed reagents / materials/analysis tools; Han Li wrote the paper.

Conflicts of Interest: The authors declare no conflict of interest. 


\section{References}

1. Zhao, Y.; Hao, R.; Yuan, B.; Jiang, J. Simultaneous removal of $\mathrm{SO}_{2}, \mathrm{NO}$ and $\mathrm{Hg}-0$ through an integrative process utilizing a cost-effective complex oxidant. J. Hazard. Mater. 2016, 301, 74-83. [CrossRef] [PubMed]

2. Zhang, Y.S.; Li, C.M.; Yu, C.; Tran, T.; Guo, F.; Yang, Y.Q.; Yu, J.; Xu, G.W. Synthesis, characterization and activity evaluation of $\mathrm{Cu}$-based catalysts derived from layered double hydroxides (LDHs) for $\operatorname{DeNO}(\mathrm{x})$ reaction. Chem. Eng. J. 2017, 330, 1082-1090. [CrossRef]

3. Liu, Y.X.; Wang, Y.; Liu, Z.Y.; Wang, Q. Oxidation Removal of Nitric Oxide from Flue Gas Using UV Photolysis of Aqueous Hypochlorite. Environ. Sci. Technol. 2017, 51, 11950-11959. [CrossRef] [PubMed]

4. Wu, H.; Pan, D.P.; Zhang, R.; Yang, L.J.; Peng, Z.M.; Yang, B. Reducing fine particle emissions by heterogeneous vapor condensation after wet desulfurization process. J. Chem. Technol. Biotechnol. 2017, 92, 2342-2350. [CrossRef]

5. Wu, C.Y.; Chou, M.S. Reduction of nitrogen dioxide from etching vent gases by scrubbing with caustic sodium sulfide solution. J. Chem. Technol. Biotechnol. 2014, 89, 1850-1858. [CrossRef]

6. Yang, S.L.; Pan, X.X.; Han, Z.T.; Zhao, D.S.; Liu, B.J.; Zheng, D.K.; Yan, Z.J. Removal of $\mathrm{NO}_{x}$ and $\mathrm{SO}_{2}$ from simulated ship emissions using wet scrubbing based on seawater electrolysis technology. Chem. Eng. J. 2018, 331, 8-15. [CrossRef]

7. Zouzelka, R.; Rathousky, J. Photocatalytic abatement of $\mathrm{NO}_{\mathbf{x}}$ pollutants in the air using commercial functional coating with porous morphology. Appl. Catal. B-Environ. 2017, 217, 466-476. [CrossRef]

8. Angelo, J.; Andrade, L.; Madeira, L.M.; Mendes, A. An overview of photocatalysis phenomena applied to $\mathrm{NO}_{\mathrm{x}}$ abatement. J. Environ. Manag. 2013, 129, 522-539. [CrossRef] [PubMed]

9. Boyjoo, Y.; Su, H.Q.; Liu, J.; Pareek, V.K.; Wang, S.B. A review on photocatalysis for air treatment: From catalyst development to reactor design. Chem. Eng. J. 2017, 310, 537-559. [CrossRef]

10. Jablonska, M.; Palkovits, R. Nitrogen oxide removal over hydrotalcite-derived mixed metal oxides. Catal. Sci. Technol. 2016, 6, 49-72. [CrossRef]

11. Yen, H.W.; Ho, S.H.; Chen, C.Y.; Chang, J.S. $\mathrm{CO}_{2}, \mathrm{NO}_{\mathrm{x}}$ and $\mathrm{SO}_{\mathrm{x}}$ removal from flue gas via microalgae cultivation: A critical review. Biotechnol. J. 2015, 10, 829-839. [CrossRef] [PubMed]

12. Ji, B.; Yang, K.; Zhu, L.; Jiang, Y.; Wang, H.Y.; Zhou, J.; Zhang, H.N. Aerobic denitrification: A review of important advances of the last 30 years. Biotechnol. Bioprocess. Eng. 2015, 20, 643-651. [CrossRef]

13. Yang, L.; Ren, Y.X.; Zhao, S.Q.; Liang, X.; Wang, J.P. Isolation and characterization of three heterotrophic nitrifying-aerobic denitrifying bacteria from a sequencing batch reactor. Ann. Microbiol. 2016, 66, 737-747. [CrossRef]

14. De Morais, M.G.; Vieira Costa, J.A. Bioprocesses for removal of carbon dioxide and nitrogen oxide by microalgae for the utilization of gas generated during coal burning. Quim. Nova 2008, 31, 1038-1042.

15. Li, H.; Huang, S.B.; Wei, Z.D.; Chen, P.F.; Zhang, Y.Q. Performance of a new suspended filler biofilter for removal of nitrogen oxides under thermophilic conditions and microbial community analysis. Sci. Total Environ. 2016, $562,533-541$.

16. Wang, H.L.; Cheng, L. Research on the Oxygenation Capacity and Energy Efficiency of Aeration Tank Impacted by Cellular Standpipe Filler; Beijing Institute of Technology: Beijing, China, 2007; pp. 1011-1014.

17. Zhao, B.; Zhang, J.; Jiang, Y. Presence of bacteria in aqueous solution influences virus adsorption on nanoparticles. Environ. Sci. Pollut. Res. 2013, 20, 8245-8254. [CrossRef] [PubMed]

18. Jiang, S.; Peng, L.; Guo, R.; Miao, D.; Shang, S.; Xu, J.; Li, A. Preparation and characterization of $\mathrm{Fe}_{2} \mathrm{O}_{3}$ coating on quartz fabric by electron beam evaporation. Ceram. Int. 2016, 42, 19386-19392. [CrossRef]

19. Lu, M.; Xia, G.-H.; Liao, R.-H.; Zhao, X.-D. Preparation and modification of porous lightweight ceramsite and its performance investigation. Desalination Water. Treat. 2013, 51, 4651-4657. [CrossRef]

20. Chen, J.N.; Truesdail, S.; Lu, F.H.; Zhan, G.G.; Belvin, C.; Koopman, B.; Farrah, S.; Shah, D. Long-term evaluation of aluminum hydroxide-coated sand for removal of bacteria from wastewater. Water Res. 1998, 32, 2171-2179. [CrossRef]

21. Cho, E.; Galera, M.M.; Lorenzana, A.; Chung, W.-J. Ethylbenzene, o-Xylene, and BTEX Removal by Sphingomonas sp. D3K1 in Rock Wool-Compost Biofilters. Environ. Eng. Sci. 2009, 26, 45-52. [CrossRef]

22. Qiu, L.; Zhang, S.; Wang, G.; Du, M.A. Performances and nitrification properties of biological aerated filters with zeolite, ceramic particle and carbonate media. Bioresour. Technol. 2010, 101, 7245-7251. [CrossRef] [PubMed] 
23. Ji, B.; Wang, H.; Yang, K. Nitrate and COD removal in an upflow biofilter under an aerobic atmosphere. Bioresour. Technol. 2014, 158, 156-160. [CrossRef] [PubMed]

24. Zhang, Y.; Li, N.; Luo, R.; Zhang, Y.; Zhou, Q.; Chen, X. Experimental study on thermal effect on infiltration mechanisms of glycerol into ZSM-5 zeolite under cyclic loadings. J. Phys. D-Appl. Phys. 2016, 49. [CrossRef]

25. Qiu, H.; Liang, C.; Yu, J.; Zhang, Q.; Song, M.; Chen, F. Preferable phosphate sequestration by nano-La(III) (hydr)oxides modified wheat straw with excellent properties in regeneration. Chem. Eng. J. 2017, 315, 345-354. [CrossRef]

26. Guzek, Z. The effect of modifying agents on the structure and electromechanical properties of steatite materials. Szklo I Ceram. 1972, 23, 137-144.

27. Zhou, H.; Feng, S.; Dongdong, C.; Chun, Z.; Xuehong, G.; Nanping, X. Improvement of hydrogen-separating performance by on-stream catalytic cracking of silane over hollow fiber MFI zeolite membrane. Int. J. Hydrogen Energy 2013, 38, 8409-8414.

28. Bao, T.; Chen, T.H.; Tan, J.; Wille, M.L.; Zhu, D.; Chen, D.; Xi, Y.F. Synthesis and performance of iron oxide-based porous ceramsite in a biological aerated filter for the simultaneous removal of nitrogen and phosphorus from domestic wastewater. Sep. Purif. Technol. 2016, 167, 154-162. [CrossRef]

29. Bao, T.; Chen, T.H.; Qing, C.S.; Xie, J.J.; Frost, R.L. Development and application of Palygorskite porous ceramsite in a biological aerated filter (BAF). Desalination Water. Treat. 2016, 57, 1790-1803. [CrossRef]

30. Liu, H.B.; Chen, T.H.; Frost, R.L. An overview of the role of goethite surfaces in the environment. Chemosphere 2014, 103, 1-11. [CrossRef] [PubMed]

31. Liang, W.; Huang, S.; Yang, Y.; Jiang, R. Experimental and modeling study on nitric oxide removal in a biotrickling filter using Chelatococcus daeguensis under thermophilic condition. Bioresour. Technol. 2012, 125, 82-87. [CrossRef] [PubMed]

32. Samuelsson, R.; Burvall, J.; Jirjis, R. Comparison of different methods for the determination of moisture content in biomass. Biomass Bioenergy 2006, 30, 929-934. [CrossRef]

33. Kostura, B.; Kulveitova, H.; Lesko, J. Blast furnace slags as sorbents of phosphate from water solutions. Water Res. 2005, 39, 1795-1802. [CrossRef] [PubMed]

34. Jiang, R.; Huang, S.; Chow, A.T.; Yang, J. Nitric oxide removal from flue gas with a biotrickling filter using Pseudomonas putida. J. Hazard. Mater. 2009, 164, 432-441. [CrossRef] [PubMed]

35. Delhomenie, M.C.; Heitz, M. Biofiltration of air: A review. Crit. Rev. Biotechnol. 2005, 25, 53-72. [CrossRef] [PubMed]

36. Raj, I.; Vaidya, A.N.; Pandey, R.A.; Bansiwal, A.; Deshmukh, S.; Purohit, H.J. Recent advancements in the mitigation of obnoxious nitrogenous gases. J. Environ. Manag. 2018, 205, 319-336. [CrossRef] [PubMed]

37. Schiavon, M.; Ragazzi, M.; Rada, E.C.; Torretta, V. Air pollution control through biotrickling filters: A review considering operational aspects and expected performance. Crit. Rev. Biotechnol. 2016, 36, 1143-1155. [CrossRef] [PubMed]

38. Li, W.; Li, M.; Zhang, L.; Zhao, J.; Xia, Y.; Liu, N.; Li, S.; Zhang, S. Enhanced $\mathrm{NO}_{\mathrm{x}}$ removal performance and microbial community shifts in an oxygen-resistance chemical absorption-biological reduction integrated system. Chem. Eng. J. 2016, 290, 185-192. [CrossRef]

39. Lu, B.-H.; Jiang, Y.; Cai, L.-L.; Liu, N.; Zhang, S.-H.; Li, W. Enhanced biological removal of $\mathrm{NO}_{x}$ from flue gas in a biofilter by Fe(II)Cit/Fe(II)EDTA absorption. Bioresour. Technol. 2011, 102, 7707-7712. [CrossRef] [PubMed]

40. Okuno, K.; Hirai, M.; Sugiyama, M.; Haruta, K.; Shoda, M. Microbial removal of nitrogen monoxide (NO) under aerobic conditions. Biotechnol. Lett. 2000, 22, 77-79. [CrossRef]

41. Zhou, Z.; Jing, G.; Zhou, Q. Enhanced $\mathrm{NO}_{x}$ removal from flue gas by an integrated process of chemical absorption coupled with two-stage biological reduction using immobilized microorganisms. Process Saf. Environ. Prot. 2013, 91, 325-332. [CrossRef]

42. Yang, Y.; Huang, S.; Liang, W.; Zhang, Y.; Huang, H.; Xu, F. Microbial removal of $\mathrm{NO}_{\mathrm{x}}$ at high temperature by a novel aerobic strain Chelatococcus daeguensis TAD1 in a biotrickling filter. J. Hazard. Mater. 2012, 203-204, 326-332. [CrossRef] [PubMed]

(C) 2018 by the authors. Licensee MDPI, Basel, Switzerland. This article is an open access article distributed under the terms and conditions of the Creative Commons Attribution (CC BY) license (http://creativecommons.org/licenses/by/4.0/). 